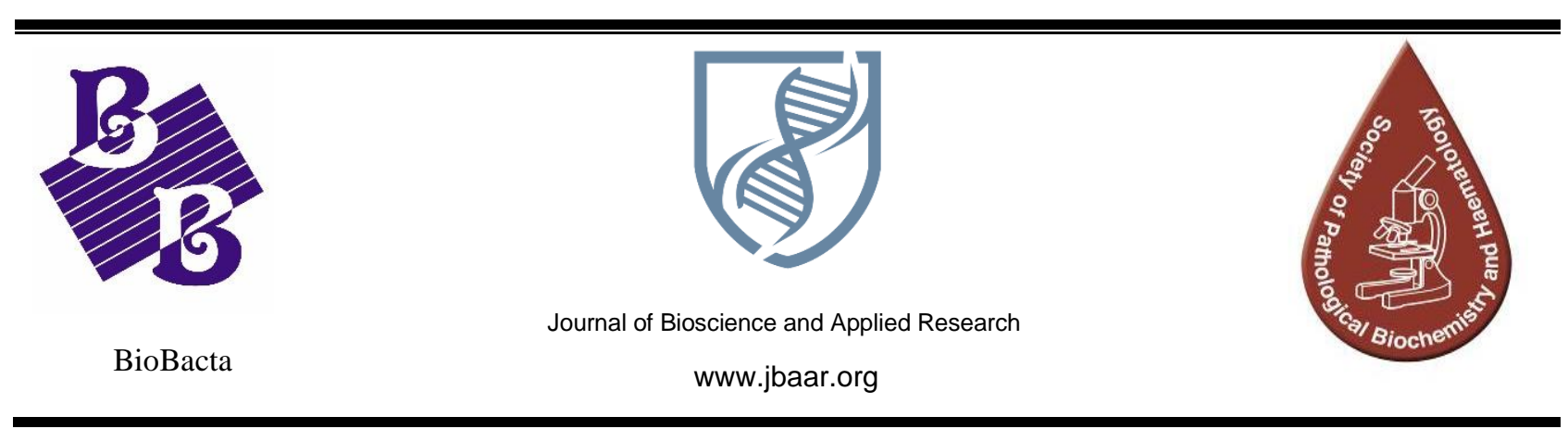

\title{
A pilot study of the paraoxonase-1 (Q192 R) gene polymorphism association with prostate cancer in the Egyptian population
}

\author{
Hany Abd Al Hamid ${ }^{1}$, Mohamed Y. Nasr ${ }^{1}$, Asmaa Ibrahim ${ }^{1,3}$, Khalid Bassiouny ${ }^{1}$, Manal \\ Mohamed Abd Al Aziz ${ }^{2}$ \\ 1. Genetic Engineering and Biotechnology Research Institute, University of Sadat City (GEBRI, USC), \\ Egypt \\ 2. Clinical Pathology Department, Faculty of Medicine, Ain shams University, Cairo, Egypt \\ 3.Diagnostic and Research Unit of Parasitic Diseases (DRUP), Department of Medical Parasitology, Kasr \\ Al-Ainy Faculty of Medicine, Cairo University, Cairo, Egypt
}

Corresponding Author: Asmaa Ibrahim* E.mail: chemistasmaain@gmail.com

ORCID: $\underline{0000-0001-8119-9549}$

Received 6/12/2019; Accepted 1/1/2020

\begin{abstract}
Background and Objectives: Prostate cancer ( $\mathrm{PCa})$ is one of the most common cancer types in men and recognized as the fifth cause of death globally. Human paraoxanase-1 (PON1) is an enzyme synthesized in the liver and linked with high-density lipoprotein (HDL). The current study aimed to evaluate the association between PCa and PON1 enzyme polymorphism in Egyptian patients. Subjects and methods: A total of 100 persons. Fifty patients diagnosed as PCa patients (group I) along with fifty non-PCa (group II) of matchable age were enrolled in this study. Patients with another type of cancer or any chronic disease were excluded. Prostate-specific antigen (PSA) was assayed in all subject's study by using ELISA Kit Protocol (Cat. No.: EK310-19); in addition to CBC, hematological parameters (hemoglobin, total leucocyte count, and platelets count) were estimated by using an automated hematology analyzer (Pentra 80) according to manufacturer's instructions. PON1 Q192R gene polymorphism was performed using polymerase chain reaction-restriction fragment length polymorphism (PCR-RFLP) technique. Results: PON1 (Q192R) gene polymorphism showed QR genotype in PCa patients (group I) [32(64\%)] compared with non-PCa (group II) [4(8\%)]. The association between PON1 (Q192R) gene polymorphism with prostate cancer group and PSA were statistically significant $(\mathrm{P}$ value $=0.000)$. Hemoglobin showed a significant association with PCa patients (group I) and PSA (P = 0.000), while total leucocyte count and platelet count showed non-significant when compared with the control group. Conclusion: Such findings showed that PON1 (Q192R) gene polymorphism could be associated with prostate cancer and disease growth. Recommendation, furthermore comprehensive studies are required to confirm the role of PON1 gene polymorphism in the etiology of PCa.
\end{abstract}

Key words: PCa, PON1 192, PSA, Polymorphism, PCR-RFLP 


\section{Introduction}

Globally about 14.1 million individuals with cancer and 8.2 million deaths were reported in 2012 as a result of cancer, which showed that cancer as a critical public health problem (Torre et al., 2015). According to the knowledge cancer is a disorder resulting from a consequence of interactions between genetic variation and environmental factors (Pharoah et al., 2004; Bredberg, 2011).

Prostate cancer $(\mathrm{PCa})$ is the most common malignant carcinoma in people, it has been identified as the second most common cancer and as the fifth leading cause of tumor death worldwide. (Center et al., 2012; Bray et al., 2018). Approximately 1.3 million cases newly diagnosed as PCa patients and 359000 leading to deaths in 2018, which showed the disease as the main health problem in men (Bray et al., 2018). The incidence and development of $\mathrm{PCa}$ are affected not only by environmental conditions but also by genetic factors. Estimated risk factors for $\mathrm{PCa}$ include age, lifestyle, familial inherited and hormonal profile, but the exact etiology is inconspicuous (Stein and Flanagan 2010).

There are many factors that may play an essential role in the susceptibility to cancer and one of these is Oxygen Free Radicals (OFR) that are constantly produced in cells (Vera-Ramirez et al., 2011). OFR stimulates oxidation of DNA bases, which form mutagenic lesions and invigorate chemical carcinogens to become highly reactive compounds (Barry et al., 2015).

Human Paraoxanase-1 (PON1) is an esterase enzyme that $\mathrm{Ca}^{++}$dependent which contributes to the ejection of OFR, synthesized in the liver, and is linked with high-density lipoprotein (HDL) and has highly lipophilic antioxidant characteristics. PON1 has two essential roles: detoxifying organophosphate compounds such as Paraoxone and protecting LDL by hydrolysis of lipid peroxides which effect DNA bases and become cytotoxic and mutagenic (Eroglu et al., 2013). Several molecular studies have shown two prevalent functional single-nucleotide polymorphisms (SNPs), L55M and Q192R, in the coding region of the PON1 gene (Mackness et al.,
1998). PON1 L55M and/or Q192R polymorphism(s) are known with their association with increased risk of prostate cancer (Fang et al., 2012; Zhang et al., 2015; Chen et al., 2016).

The main objective of this study was to identify the association of the PON1 192 genotypes and Q and R allelic frequencies in Egyptian PCa patients (group I) compared with a healthy group (group II)

\section{Subjects and methods}

\section{Study design and study population}

A total of 100 persons who had admitted to the urology department in the Faculty of Medicine, Ain shams university, Egypt, between September 2017, and June 2018. Fifty patients were clinically diagnosed and confirmed to be prostatic cancer patients (group I) by laboratory investigations. Fifty healthy control subjects were included in this study as non- PCa (group II). Patients with other types of cancer or chronic diseases were excluded from this study. All investigations were performed in accordance with the Ain Shams University, Health and Human Ethical Clearance Committee guidelines for Clinical Researches. The local ethics committee approved the study protocol and Informed consent was got from all subjects.

\section{Sample Collection}

$5 \mathrm{ml}$ of venous blood was collected from all subjects by plastic disposable syringes. Each sample was divided into two-part. The first part put into sterile vacutainer tubes containing Ethylene diamine tetra acetic acid (EDTA) for DNA extraction to identify PON1 Q192R gene polymorphism by using polymerase chain reaction restriction fragment length polymorphism (PCR-RFLP) technique and complete blood count $(\mathrm{CBC})$ analysis by using automated hematology analyzer, the Pentra 80 . The second part was centrifuged at $1500 \mathrm{rpm}$ for 10 minutes to separate serum samples and stored at $-20^{\circ} \mathrm{C}$ to identify PSA level by using ELISA Kit Protocol (Cat. No.: EK-310-19) and other biochemical parameters.

\section{Biochemical analysis}

Biochemical analysis and molecular analysis were performed in the clinical department and in molecular immunology lab respectively in Genetic Engineering 
and Biotechnology Research Institute (GEBRI), University of Sadat City.

\section{Molecular analysis \\ DNA Extraction}

Genomic DNA was extracted from blood samples using Thermo fisher spin columns, isolation mini kit (cat.no K0781) according to the manufacturer's instructions. The extracted DNA was stored at $-20^{\circ} \mathrm{C}$ until used.

Conventional Polymerase chain reaction for PON1 (Q192R) gene polymorphism

Conventional PCR was performed and the following primers were used: forward primer 5'TATTGTTGCTGTGGGACCTGAG-3'; reverse primer 5'-CCTTCTGCCACCACTCGAAC-3'; The PCR mixture (total, $25 \mu \mathrm{l}$ ) consisted of $6 \mu \mathrm{l}$ DNA, 1 $\mu \mathrm{l}$ of each primer, 4.5 of free nucleases water and 12.5 $\mu 1$ of master mix (cat no K0171). The PCR cycling condition consisted of $95^{\circ} \mathrm{C}$ for 2 minutes, followed by 35 cycles of $94^{\circ} \mathrm{C}$ for 1 minute to denature, $61^{\circ} \mathrm{C}$ for 1 minute to anneal the primers and $72^{\circ} \mathrm{C}$ for 1 minute to elongate the strand.

\section{Restriction-fragment length polymorphism analysis (RFLP)}

RFLP analysis was conducted according to the manufacturer's instructions with Alwl (BspI) (product no.; ER 1321 Thermo Scientific). After the PCR amplification reaction, the restriction products were detected on $2 \%$ agarose gel electrophoresis after ethidium bromide staining and gels were recorded by UV transillumination. Digestion produced the following fragments: PON1 192 R allele, fragments of $66 \mathrm{bp}$ and $33 \mathrm{bp}$; PON1 192 Q allele, a single fragment of $99 \mathrm{bp}$.

\section{Statistical analysis}

Statistical analyses were carried out using the Social Sciences software version 17.0 for Windows (SPSS Inc.; Chicago, IL, USA) Statistical Kit. T-test was used to compare parametric variables, Categorical data and the frequencies of genotype and allele among the groups were compared using the $c h i$ square test. Descriptive analysis included biochemical tests of means and the respective standard deviation (SD) for cases and controls.

\section{Results}

Fifty subjects were enrolled in the PCa group and fifty healthy persons were enrolled in the non-PCa group. PCa patient group included patients with mean ages $66.94 \pm 12.119$ years

\section{PON1 (Q192R) gene polymorphism and PCa risk}

The Q/R genotype was the most frequent genotype detected in the PCa group 32(64\%) versus 4(8\%) in the non-PCa group $(\mathrm{p}=0.000)$. the $\mathrm{R} / \mathrm{R}$ genotype and $\mathrm{Q} / \mathrm{Q}$ genotype are non-significant differences in $\mathrm{PCa}$ group and non-PCa group. The distributions of PON1 (Q192R) gene polymorphism and genetic and allelic variations in all groups are presented in (Table 1)

Serum PSA levels were higher in the PCa group compared to the non-PCa group $(\mathrm{p}<0.05)$. The distribution of PSA level in the PCa group and nonPCa group are presented in (Table 2) and the distribution of PON1 (Q192R) gene polymorphism with PSA level are presented in (Table 3)

Table 1: Distribution of PON1 (Q192R) gene polymorphism in Pca and Non-Pca

\begin{tabular}{cccc}
\hline PON 192Q/R & $\begin{array}{c}\text { Pca } \\
\text { (group I) } \\
\text { N=50 }\end{array}$ & $\begin{array}{c}\text { Non-Pca } \\
\text { (group II) } \\
\text { N=50 }\end{array}$ & P value \\
\hline Q/Q & $14(28 \%)$ & $42(84 \%)$ & $\mathbf{0 . 0 0 0 *}^{*}$ \\
\hline $\mathbf{Q} / \mathbf{R}$ & $32(64 \%)$ & $4(8 \%)$ & \\
\hline $\mathbf{R} / \mathbf{R}$ & $4(8 \%)$ & $4(8 \%)$ & $\mathbf{0 . 2}$ \\
\hline $\mathbf{Q}$ & & & \\
\hline $\mathbf{R}$ & $60(60 \%)$ & $88(88 \%)$ & \\
\hline Allele frequencies & $40(40 \%)$ & $12(12 \%)$ & \\
\hline
\end{tabular}

(*) $P$ value $<0.05$ is significant. 
Table 2: Distribution of PSA level in PCa group and non-PCa group

\begin{tabular}{cccc}
\hline Prostate & $\begin{array}{c}\text { PSA } \\
\text { Normal }\end{array}$ & $\begin{array}{c}\text { PSA } \\
\text { Abnormal }\end{array}$ & P value \\
\hline Pca & $0(0 \%)$ & $50(92.6)$ & $\mathbf{0 . 0 0 0}$ \\
\hline Non-Pca & $46(46 \%)$ & $4(7.4)$ & \\
\hline
\end{tabular}

(*) $P$ value $<0.05$ is significant.

Table 3: Distribution of PON1 (Q192R) gene polymorphism with PSA level

\begin{tabular}{cccc}
\hline PON1 192Q/R & $\begin{array}{c}\text { PSA } \\
\text { Normal }\end{array}$ & $\begin{array}{c}\text { PSA } \\
\text { Abnormal }\end{array}$ & P value \\
\hline Q/Q & $38(67.8 \%)$ & $18(32.2 \%)$ & $\mathbf{0 . 0 0 1}^{*}$ \\
\hline Q/R & $4(11.1 \%)$ & $32(59.2 \%)$ & \\
\hline R/R & $4(11.1 \%)$ & $4(8.6 \%)$ & $\mathbf{0 . 8 0}$ \\
\hline Allele frequencies & & & \\
\hline $\mathbf{Q}$ & $80(87 \%)$ & $68(62.96 \%)$ & \\
\hline $\mathbf{R}$ & $12(13 \%)$ & $40(37.04 \%)$ & \\
\hline
\end{tabular}

(*) $P$ value $<0.05$ is significant.

\section{Complete blood count and prostate cancer}

Hemoglobin showed a significant association with prostate cancer $(\mathrm{P}=0.000)$. While total leucocyte count and platelet count showed a non-significant association with prostate cancer (Table 4).

Table 4: Hematological parameters association with prostate cancer

\begin{tabular}{cccc}
\hline Hematological Parameters & Normal & Abnormal & P value \\
\hline Hemoglobin & & & $\mathbf{0 . 0 0 0}$ \\
\hline PCa & $10(20 \%)$ & $40(80 \%)$ & $12(24 \%)$ \\
\hline Non-PCa & $38(76 \%)$ & & $\mathbf{0 . 6 4 9}$ \\
\hline Total leucocyte count & & $42(84 \%)$ & $\mathbf{0 . 5 0}$ \\
\hline PCa & $42(84 \%)$ & $8(16 \%)$ & \\
\hline Platelets count & $8(16 \%)$ & & $2(4 \%)$ \\
\hline PCa & $48(96 \%)$ & $4(8 \%)$ & \\
\hline Non-PCa & $46(92 \%)$ & & \\
\hline
\end{tabular}

(*) $P$ value $<0.05$ is significant

\section{Discussion}

Globally prostate cancer is the most prevalent episodic cancer and recognized as the second rife mortal cancer among men (Saman et al., 2014). Previous studies of PON1 polymorphisms showed conflicting results about the association between PON1 polymorphisms and cancer. Recently, more attention is being paid to research based on the relationship between genetic variation and cancer etiopathogenesis. In those studies, the association between cancer and the genetic polymorphism has been reported for bladder, liver, lung and kidney cancers. But about prostate cancer (Pca) there seems to be a restricted number of studies on the association between it and genetic polymorphisms of PON-1 (Fang et al., 2012).

The implied molecular mechanisms for the association between $\mathrm{PON}-1$ polymorphism not only 
with initiation but also for the development of various malignancies types of inclusively PCa (Mao et al., 2010 and Liwei et al., 2012). Polymorphisms of PON1 Q192R are the most common polymorphism studied in previous cancer-related studies. Mutations in 192 codons have been reported in molecular studies, the substitution of $\mathrm{Q}$ by $\mathrm{R}$ allele at position 192 of the PON1 gene leads to the formation of arginine instead of glutamine (Lurie et al., 2008).

The present study of PON-1 Q192R gene polymorphism found that the existence of the variant alleles of the heterozygous PON-1 Q192R, resulting in the substitution of amino acids, increased the risk of prostate cancer, whereas homozygous (QQ and RR) showed safety against prostate cancer. This association was statistically significant $(\mathrm{P}=0.000)$. These findings agreeing with (Kerridge et al., 2002, Antognelli et al., 2005) who reported previously the protective effect of heterozygous form. In addition (Jarvik et al., 2003) reported that the combination of QR alleles (heterozygous) genotype was associated with a greater than double risk of prostate cancer.

Hematological parameters such as hemoglobin, total leucocyte count and platelet count disturbance have been reported in a large number of diseases. Anemia the most frequent sign that occurs in advanced prostate cancer (Nalesnik et al., 2004). Testosterone could promote the generation of renal erythropoietin, so men with prostate cancer commonly have anemia (Ellegala et al., 2003). The findings of this study showed that the anemia was correlated substantially with worse prostate cancer prognosis. The association between hemoglobin and prostate cancer is statistically significant $(\mathrm{P}=0.000)$. There is little epidemiological evidence which supports an association between total leucocyte count and PCa, while in another study, the monocyte fraction of total leucocyte count was reported to be high count in men prostatic cancer patients (Hayashi et al., 2016). There is weak evidence was reported elevation of leucocyte levels at the time of prostatic cancer patients than healthy men (Toriola et al., 2013). In the present study total leucocyte count not showed any association with prostate cancer. The association between the raised platelet counts and cancer itself remains unknown. It has been suggested that tumor-derived thrombopoietic cytokines lead to paraneoplastic thrombocytosis (Stone, et al., 2012). In the present study the association of platelet count and prostate cancer, are not statistically significant.

In the present study, the results showed that PON1 Q192R polymorphism associated with PSA level, abnormal PSA more prevalent in patients with $\mathrm{QR}$ (heterozygotes) than patients with QQ and RR alleles, this different is statistically highly significant $(\mathrm{P}=0.000)$.

\section{Conclusion}

These results investigated that increase the susceptibility of prostate cancer in the case of QR (heterozygous genotype) than RR (homozygous genotype) and the QQ (homozygous genotype). This research has found an important correlation between prostate cancers and anemia. Recommendations, further investigations to clarify the possible role of PON1 gene polymorphism in the etiology of $\mathrm{PCa}$ on large sample size are still needed.

\section{References}

Antognelli C, Mearini L, Talesa VN, et al (2005): Association of CYP17, GSTP1, and PON1 polymorphisms with the risk of prostate cancer. Prostate, 63, 240-51.

Barry KH, Moore LE, Liao LM, Huang WY, Andreotti G, Poulin M, et al. (2015): Prospective study of DNA methylation at LINE-1 and Alu in 
peripheral blood and the risk of prostate cancer. Prostate 75:1718-25.

Bray, F., Ferlay, J., Soerjomataram, I. et al. (2018): Global cancer statistics 2018. GLOBOCAN estimates of incidence and mortality worldwide for 36 cancers in 185 countries. CA Cancer J. Clin. 68, 394-424.

Bredberg A, (2011): Cancer: more of polygenic disease and less of multiple mutations? A quantitative viewpoint. Cancer, 117, 440-5.

Center, M.M., Jemal, A., Lortet-Tieulent, J. et al. (2012): International variation in prostate cancer incidence and mortality rates. Eur. Urol. 61, 1079-92 Chen L, Lu W, Fang L, Xiong H, Wu X, Zhang M, Wu S, Yu D (2016): Association between L55M polymorphism in Paraoxonase 1 and cancer risk: a meta-analysis based on 21 studies. Onco Targets Ther. 9:1151-58.

Ellegala DB, Alden TD, Couture DE, Vance ML, Maartens NF and Laws EJ (2003): Anemia, testosterone, and pituitary adenoma in men. J Neurosurg 98: 974-977.

Eroglu M, Yilmaz N, Yalcinkaya S, Ay N, Aydin O, Sezer C (2013): Enhanced HDL-cholesterolassociated antioxidant PON-1 activity in prostate cancer patients. Kaohsiung J Med Sci 29:368-73.

Fang DH, Fan CH, Ji Q, Qi BX, Li J, Wang L (2012): Differential effects of paraoxonase 1 (PON1) polymorphisms on cancer risk: evidence from 25 published studies. Mol Biol Rep 39:6801-09.

Hayashi T, Fujita K, Tanigawa G, et al. (2016): Serum monocyte fraction of white blood cells is increased in patients with high Gleason score prostate cancer. Oncotarget 8:35255-61.

Jarvik GP, Hatsukami TS, Carlson C, Richter RJ, Jampsa R, Brophy VH, Margolin S, Rieder M, Nickerson D, Schellenberg GD, Heagerty PJ, Furlong CE. (2003): Paraoxonase activity, but not haplotype utilizing the linkage disequilibrium structure, predicts vascular disease. Arterioscler Thromb Vasc Biol23: 1465-71.

Kerridge I, Lincz L, Scorgie F, et al (2002): Association between xenobiotic gene polymorphisms and non-Hodgkin's lymphoma risk. Br J Haematol, $118,477-81$.

Liwei L, Wei Z, Ruifa H, Chunyu L. (2012): Association between genetic variants in glutathione peroxidase 1 gene and risk of prostate cancer: a metaanalysis. Mol Biol Rep 39:8615-9.

Lurie G, Wilkens LR, Thompson PJ, McDuffie KE, Carney ME, Terada KY, et al. (2008): Genetic polymorphisms in the Paraoxonase 1 gene and risk of ovarian epithelial carcinoma. Cancer Epidemiol Biomarkers Prev 17:2070-7.

Mackness BM, Mackness MI, Arrol S, Turkie W and Durrington PN (1998): Effect of the human serum paraoxonase 55 and 192 genetic polymorphisms on the protection by high density lipoprotein against low density lipoprotein oxidative modification. FEBS Lett 423: 57-60.

Mao C, Qiu LX, Zhan P, Xue K, Ding H, Du FB, et al. (2010): MnSOD Val16Ala polymorphism and prostate cancer susceptibility: a meta-analysis involving 8962 subjects. J Cancer Res Clin Oncol 136:975-9.

Nalesnik JG, Mysliwiec AG, Canby-Hagino E (2004): Anemia in men with advanced prostate cancer: incidence, etiology, and treatment. Rev Urol $6: 1-4$

Pharoah PD, Dunning AM, Ponder BA, et al (2004): Association studies for finding cancersusceptibility genetic variants. Nat Rev Cancer, 4, 850-60.

Saman DM, Lemieux AM, Nawal Lutfiyya M, Lipsky MS. (2014): A review of the current 
epidemiology and treatment options for prostate cancer. Dis Mon 60:150-4.

Stein, Q.P. and Flanagan, J.D. (2010): Genetic and familial factors influencing breast, colon, prostate and lung cancers. South Dakota Med. Spec No, 16-22 Stone, R. L.et al. (2012): Paraneoplastic Thrombocytosis in Ovarian Cancer. N. Engl. J. Med. 366, 610-18.

Torre LA, Bray F, Siegel RL, et al (2015): Global cancer statistics, 2012 CA Cancer J Clin, 65, 87-108. Toriola AT, et al. (2013): Prediagnostic circulating markers of inflammation and risk of prostate cancer. Int J Cancer. 133(12):2961-7.
Vera-Ramirez L, Sanchez-Rovira P, RamirezTortosa MC, Ramirez-Tortosa CL, GranadosPrincipal S, et al. (2011): Free radicals in breast carcinogenesis, breast cancer progression and cancer stem cells. Biological bases to develop oxidativebased therapies. Crit Rev Oncol Hematol 80: 347-68 Zhang M, Xiong H, Fang L, Lu W, Wu X, Huang ZS, Wang YQ, Cai ZM, Wu S. (2015): Paraoxonase 1 (PON1) Q192R Gene Polymorphism and Cancer Risk: A Meta-Analysis Based on 30 Publications. Asian Pac J Cancer Prev.16:4457-63. 